\title{
PERGESERAN ORIENTASI KELEMBAGAAN PESANTREN DI MADURA; PERSPEKTIF KIAI DI BANGKALAN
}

\author{
Zainal Alim \\ (Institut Teknologi Adhi Tama Surabaya)
}

\begin{abstract}
Abstrak:
Pada mulanya Kiai di Bangkalan Madura tidak terlalu menerima pendidikan formal. Namun kini realitas itu mengalami pergeseran pemikiran dan prilaku yang sangat berefek pada pembaruan pendidikan Islam di Bangkalan Madura. Tulisan ini memuat tentang keterbukaan para Kiai di Bangkalan pada pendidikan umum dengan semakin banyaknya pesantren yang mempunyai kategori salafiyah mempunyai pendidikan formal mulai dari tingkat dasar hingga perguruan tinggi. Tujuan penelitian ini adalah untuk mendekripsikan pergeseran orientasi kelembagaan dalam perspektif Kiai di pesantren Syaichona Kholil dan pesantren Al-Hidayah Bangkalan Madura. Dalam penelitian ini, penulis menggunakan metode penelitian dengan pendekatan deskriptif kualitatif. Sementara, sumber data primer diperoleh dari Kiai Pengasuh Pondok Pesantren Syaichona Kholil Bangkalan, pengasuh pesantren Al-Hidayah, Ketua Pondok dan sumber sekunder yang relevan. Hasil dari penelitian ini adalah bahwa terjadi pergeseran orientasi kelembagaan di pesantren dengan banyaknya lembaga pendidikan formal seperti MTs, MA, bahkan Perguruan Tinggi di beberapa pesantren yang ada di Bangkalan. Pergeseran ini tidak lepas dari berubahnya pola pikir Kiai yang disebabkan oleh globalisasi, teknologi yang semakin canggih, dan sulitnya para alumni santri mendapatkan peluang pekerjaan di instansi-instansi umum.
\end{abstract}

Kata Kunci: Orientasi Kelembagaan, Pesantren, Kiai, Madura 


\begin{abstract}
:
In the beginning, Kiai in Madura didn't accept formal schooling. However, the reality today shows thought and attitude shifts which takes effect on the renewal of Islamic Education in Bangkalan, Madura. This paper examines the openness of Kiai in Bangkalan towards formal education as it is indicated by the emerging more Salafi Pesantren with formal education ranging from elementary schooling up to higher education. This research is aimed to describe institutional orientation in Syaichona Kholil Pesantren and Al-Hidayah Pesantren in Bangkalan, Madura. Within the framework of descriptive and qualitative research, the field work involves primary data from Kiais in the two institutions as well as secondary data from relevan resources. The finding shows that there are more and more Pesantren to adopt formal shooling in the Madrasah format and Islamic higher education due to the shift of thought in the Kiai leadership as a negotiation results of globalization, technological advancement, and the high competition for Pesantren alumni in workforce within non-religious institutions.
\end{abstract}

\title{
Keywords: Institutional Orientation, Pesantren, Kiai, Madura
}

\section{A. Pendahuluan}

Pesantren secara historis telah mendokumentasikan berbagai peristiwa sejarah bangsa Indonesia. Sejak awal penyebaran agama Islam di Indonesia, pesantren merupakan saksi utama dan sarana penting bagi kegiatan Islamisasi tersebut. Perkembangan dan kemajuan masyarakat Islam Nusantara, tidak mungkin terpisahkan dari peranan yang dimainkan pesantren. Besarnya arti pesantren dalam perjalanan bangsa Indonesia yang harus dipertahankan. Apalagi pesantren telah dianggap sebagai lembaga pendidikan yang mengakar kuat dari budaya asli bangsa Indonesia. ${ }^{1}$

Pada tahun 70-an, Abdurrahman Wahid, telah mempopulerkan pesantren sebagai sub-kultur dari bangsa Indonesia. Sekarang ini, umat Islam sendiri tampaknya telah menganggap pesantren sebagai model institusi pendidikan yang memiliki keunggulan, baik dari sisi transmisi dan internalisasi moralitas umat Islam² maupun dari aspek tardisi keilmuan yang oleh Martin Van Bruinessen dinilainya sebagai salah satu tradisi agung (great tradition). ${ }^{3}$ Akan tetapi di samping hal-hal yang mengembirakan tersebut di atas, perlu pula dikemukakan beberapa tantangan pondok pesantren dewasa ini.

\footnotetext{
${ }^{1}$ Hanun Asrorah, Sejarah Pendidikan Islam (Jakarta: Logos Wacana Ilmu, 1999), 184.

${ }^{2}$ Asrohah, Sejarah Pendidikan Islam, 126.

3 Martin Van Bruinessen, Kitab Kuning, Pesantren, dan Tarekat : Tradisi-Tradisi Islam di Indonesia (Bandung: Mizan, 1999), 17.
} 
Lingkungan pesantren merasa bahwa sesuatu yang bersifat modern, yang selalu mereka anggap datang dari Barat, berkaitan dengan penyimpangan terhadap agama. ${ }^{4}$ Oleh sebab itu, mereka melakukan isolasi diri terhadap sentuhan perkembangan modern sehingga membuat pesantren dinilai sebagai penganut Islam tradisional. Padahal, menurut Muhammad Hasan, pesantren diharuskan untuk melakukan inovasi dan modernisasi agar pesantren menyesuaikan dengan perubahan sosial. Maka, harus dilakukan perubahan pada aspek metode, isi materi dan manajemen pengelolanya. ${ }^{5}$ Konsep modernisasi pendidikan pesantren pernah disinggung oleh Muhammad Anwar. Menurutunya, dalam proses modernisasi pendidikan pesantren perlu dipahami terlebih dahulu ide dasar modernisasi di bidang pendidikan secara umum. ${ }^{6}$ Dari dua tulisan tersebut, maka perubahan dalam pendidikan pesantren harus dicermati, dikaji dan dipahami dengan baik. Sehingga pesantren tidak hanya modern secara formasi, tetapi juga secara substansi.

Realitasnya, masih ada pesantren yang eksklusif dari perubahan sosial. Pendidikan Islam tradisional ini pun terkadang hanya diorientasikan kepada tujuan akhirat semata, dan di sisi lain (sebagian kecil) mengejar orientasi kemanusiaan tapi kehilangan tujuan yang bersifat akhirat. Sehingga pendidikan pesantren cenderung defensif, yaitu sekedar untuk menyelamatkan kaum muslimin dari pencemaran dan pengrusakan yang ditimbulkan dampak gagasan Barat yang datang melalui disiplin ilmu, terutama gagasan yang mengancam akan meledakkan standar-standar moralitas tradisi awal Islam. ${ }^{7}$ Maka perubahan pendidikan pesantren harus terbuka terhadap nilai-nilai insaniyah yang rumusannya dihasilkan oleh siapapun, karena Islam mengakui eksistensi keberadaan suku adat istiadat suatu bangsa dan kelompok lain.

Masyarakat Madura sebagai suatu bangsa yang berada dalam satu pulau mempunyai sejarah, struktur sosial, bahasa, adat istiadat, serta agama. Hal ketiga terakhir merupakan sumber perekat utama masyarakat Madura. Oleh karena itu, masyarakat Madura sangat mudah dalam berinteraksi baik di daerah sendiri maupun diluar daerah serta mempunyai rasa memiliki antara satu dengan yang lain sangat tinggi. Masyarakat Madura mempunyai empat ciri umum di antaranya

${ }^{4}$ Azumardi Azra, "Pesantren : Kontinuitas dan Perubahan", Pengantar dalam Nucholis Madjid, Bilik-Bilik Pesantren : Sebuah Potret Perjalanan (Jakarta : Paramida, 1997), xvi.

5 Muhammad Hasan, "Inovasi dan Modernisasi Pendidikan Pondok Pesantren". KARSA: Jurnal Sosial dan Budaya Keislaman Vol. 23 No. 2, (Desember 2015): 296-298.

6 Lihat Muhammad Anwar, "Modernisasi Pesantren; Pergeseran Tradisi dan Pudarnya Kiai". Hunafa: Jurnal Studia Islamika Vol. 10, No. 1, (Juni 2013).

7 Fazlur Rahman, Islam dan Modernitas, diterjemahkan oleh Ahsin Muhammad, (Bandung: Pustaka, 1995), Cet. 2, 160-164. 
Madurawi, Indonesiawi, Islami dan Manusiawi. ${ }^{8}$ Keempat ciri tersebut ada dalam diri semua lapisan struktur masyarakat Madura seperti pada diri Kiai/ulama', tokoh masyarakat, blater, dan masyarakat awam umumnya.

Kiai $^{9}$ merupakan bagian dari masyarakat Madura yang sangat tidak terbantahkan. Kiai mempunyai pengaruh yang besar pada setiap sendi kehidupan masyarakat Madura dalam segala aspek, seperti pendidikan, kuasa politik, ekonomi, sosial dan agama. sehingga sangat tidak mungkin mengilangkan tokoh Kiai dalam struktur masyarakat Madura ini. Kiai dikenal oleh sebagian masyarakat Madura dalam konstruk yang positif, yaitu orang yang pintar atau alim dalam pengetahuan agama Islam. Kiai adalah pengasuh sebuah lembaga pendidikan Islam, baik lembaga pendidikan Diniah saja atau Pondok pesantren.

Kiai yang merupakan kepala pendidikan Islam yang awalnya tidak terlalu menerima pendidikan formal sekarang mengalami pergeseran pemikiran dan prilaku yang sangat berefek pada pendidikan pesantren di Bangkalan Madura. Keterbukaan para Kiai di Bangkalan pada pendidikan formal dengan semakin banyaknya pesantren yang mempunyai kategori salafiyah mempunyai pendidikan formal mulai dari tingkat dasar hingga perguruan tinggi merupakan fenomena tersendiri bagi masyarakat Madura khususnya masyarakat Bangkalan.

Pergeseran orientasi kelembagaan dalam persepektif Kiai yang terjadi di Madura khususnya di Bangkalan pada struktur sosial tentu sangat berpengaruh pada pembaruan pendidikan Islam di pesantren. Walaupun pergeseran pemikiran Kiai tersebut di atas, mempunyai tujuan yang mungkin saja berbeda dari maksud sebuah proses pendidikan sebagaimana mesti dan lazimnya. Hal inilah yang sangat menarik untuk diteliti. Kiai tentu mempunyai pandangan tersendiri tentang kehadiran sekolah formal di masing-masing lembaga pendidikan Islam yang ada di pesantren-pesantren. Maka, dalam penelitian ini, penulis memaparkan pergeseran orientasi kelembagaan dalam perspektif Kiai di

${ }^{8}$ Hasil rumusan badan silaturrahim ulama' Madura (BASSRA) yang peneliti dapatkan ketika mendengarkan sambutan yang disampaikan oleh Prof.Dr. Mahfud, MD pada acara silaturrahim masyarakat Madura di Surabaya.

9 Kata "Kiai" berasal dari bahasa jawa kuno "kiya-kiya" yang artinya orang yang dihormati. Sedangkan dalam pemakaiannya dipergunakan untuk: pertama, benda atau hewan yang dikeramatkan, seperti Kiai Plered (tombak), Kiai Rebo dan Kiai Wage (gajah di kebun binatang Gembira loka Yogyakarta), kedua orang tua pada umumnya, ketiga, orang yang memiliki keahlian dalam Agama Islam, yang mengajar santri di Pesantren. Sedangkan secara terminologis menurut Manfred Ziemnek, pengertian Kiai adalah "pendiri dan pemimpin sebuah pesantren sebagi muslim "terpelajar" telah membaktikan hidupnya "demi Allah" serta menyebarluaskan dan mendalami ajaran-ajaran dan pandangan Islam melalui kegiatan pendidikan Islam. Namun pada umumnya di masyarakat kata "Kiai" disejajarkan pengertiannya dengan ulama dalam khazanah Islam. Lihat. Moch. Eksan, Kiai Kelana: biografi Kiai Muchith Muzadi (Jogjakarta: Elkis Penlangi Aksara, 2000).

Jurnal Pendidikan Agama Islam

Volume 4 Nomor 2 Nopember 2016

ISSN(p) 2089-1946\& ISSN(e) 2527-4511

Hal. 252 - 270 
Bangkalan Madura. Dalam hal ini pergeserannya adalah penerimaan lembaga pendidikan formal dalam lingkungan pondok pesantren.

\section{B. Pendidikan Pesantren dan Perubahan Sosial}

Pendidikan merupakan sistem dan cara meningkatkan kualitas hidup manusia dalam segala aspek kehidupan manusia. Dalam sejarah umat manusia, hampir tidak ada kelompok manusia yang tidak menggunakan pendidikan sebagai alat pemberdayaan dan peningkatan kualitasnya, sekalipun dalam masyarakat yang masih terbelakang (primitif). Pendidikan sebagai usaha sadar yang dibutuhkan untuk menyiapkan anak manusia demi menunjang perannya di masa datang. Upaya pendidikan yang dilakukan oleh suatu bangsa tentu memiliki hubungan yang sangat signifikan dengan rekayasa bangsa di masa mendatang, karena pendidikan merupakan salah satu kebutuhan asasi manusia, sebagaimana tersirat dalam rumusan fungsi dan tujuan pendidikan dalam undang-undang sistem pendidikan nasional, menggambarkan tentang kehendak yang akan dicapai bangsa ini untuk masyarakatnya, yaitu masyarakat yang beriman, taqwa dan berketrampilan. ${ }^{10}$

Entri point dari usaha pendidikan adalah pemberdayaan manusia, di mana pendidikan mempunyai peran sentral dalam mendorong individu dan masyarakat untuk meningkatkan kualitasnya dalam segala aspek kehidupan demi mencapai kemajuan dan peran kehidupannya di masa mendatang. Demikian ini terbukti dalam kehidupan sosial dewasa ini yaitu di mana pendidikan tampil dengan gaya pengaruh yang sangat besar dan menjadi variabel pokok masa depan manusia.

Pendidikan merupakan bagian terpenting dari kehidupan manusia yang sekaligus membedakan manusia dengan hewan. Hewan juga "belajar', tetapi lebih ditentukan oleh instink, sedangkan bagi manusia, belajar berarti rangkaian kegiatan menuju "pendewasaan" guna manuju kehidupan yang lebih berarti. ${ }^{11}$

Oleh karena itu, berbagai pandangan menyatakan pendidikan merupakan proses budaya untuk mengangkat "harkat" dan "martabat" manusia dan berlangsung sepanjang hayat. Apabila demikian, maka pendidikan memegang peranan yang menentukan eksistensi dan perkembangan manusia, "karena pendidikan merupakan usaha melestarikan dan mengalihkan serta mentransformasikan nilai-nilai kebudayaan dalam segala aspeknya dan jenisnya

${ }^{10}$ Lihat Undang-Undang RI No. 20 Tahun 2003 tentang Sistem Pendidikan Nasional (Bandung: Citra Umbara: 2003)

11 M. Rusli Karim, "Pendidikan Islam Sebagai Upaya Pembebasan Manusia" dalam Muslih Usa (ed.), Pendidikan Islam di Indonesia antara Cita dan Fakta (Yogyakarta: Tiara Wacana, 1991), 27. 
kepada generasi penerus"12 Mengingat pendidikan merupakan kebutuhan penting bagi setiap manusia, negara dan bangsa maka pendidikan harus selalu diperbarui, diberdayakan dan dikembangan secara sistematis, khususnya oleh para ahli pendidikan di negara ini.

Berangkat dari kerangka demikian ini, maka upaya pendidikan suatu bangsa berkaitan erat dengan rekayasa bangsa tersebut di masa mendatang, sebab pendidikan selalu dihadapkan pada perubahan, baik perubahan zaman maupun masyarakat. Oleh karena itu, mau tidak mau pendidikan harus didesain mengikuti irama perubahan tersebut, kalau tidak pendidikan akan ketinggalan. Tuntutan pembaruan pendidikan Islam menjadi suatu keharusan dan pembaruan pendidikan selalu mengikuti dan relevan dengan kebutuhan masyarakat, baik pada konsep, kurikulum, proses, fungsi, tujuan, manajemen lembaga-lembaga pendidikan Islam, dan sumber daya pengelolanya.

Gagasan pembaruan atau modernisasi ${ }^{13}$ pendidikan Islam di Indonesia, seperti yang dikemukakan di atas, sangat berkaitan erat dengan pertumbuhan gagasan modernisasi Islam di kawasan ini. Apabila mencermati gagasan modernisasi Islam pada awal abad 20 pada aspek atau lapangan pendidikan, direalisasikan dengan pembentukan lembaga-lembaga modern yang diadopsi dari sistem pendidikan kolonial Belanda dan kehadiran organisasi-organisasi modernis Islam seperti Jami'at Khair, al-Irsyad, Muhammadiyah dan lain-lain. Sebagai pelopor modernis, walaupun pada awal perkembangan organisasiorganisasi ini mengadopsi sistem dan lembaga pendidikan modern secara hampir menyeluruh, artinya titik tolak modernisme pendidikan Islam di sini adalah sistem dan kelembagaan pendidikan modern (Belanda), bukan sistem dan lembaga pendidikan Islam tradisional. ${ }^{14}$

Mencermati perubahan pendidikan Islam di atas, maka perubahan pendidikan pesantren merupakan suatu usaha atau proses multidimensional yang kompleks, dan tidak hanya bertujuan untuk menyempurnakan kekurangankekurangan yang dirasakan, tetapi terutama merupakan suatu usaha penelaahan

12 Karim, "Pendidikan Islam Sebagai Upaya Pembebasan Manusia", 11.

13 Kata "modern" merupakan suatu pengertian yang kurang menentu, sehingga dapat dipergunakan untuk menyifati segala macam ide, cita-cita atau keinginan-keinginan. Istilah "modernisasi" lebih sering dipergunakan untuk menunjukkan pertumbuhan pemikiran atau penemuan-penemuan yang serba rasional. Harun Nasution menyatakan bahwa dalam bahasa Indonesia telah dan selalu dipakai kata modern, modernisasi dan modernisme. Menurutnya modernisasi dalam masyarakat Barat mengandung arti pikiran, aliran, gerakan, dan usaha untuk merubah paham-paham, adat istiadat, institusi-institusi lama, dan sebagainya, untuk disesuaikan dengan suasana baru yang ditimbulkan oleh kemajuan ilmu pengetahuan dan teknologi modern

${ }_{14}$ Azyumardi Azra, Pendidikan Islam; Tradisi dan Modernisasi Menuju Milenium Baru (Jakarta: Logos Wacana Ilmu, 1999), 57.

Jurnal Pendidikan Agama Islam

Volume 4 Nomor 2 Nopember 2016

ISSN(p) 2089-1946\& ISSN(e) 2527-4511

Hal. 254 - 270 
kembali atas aspek-aspek sistem pendidikan pesantren yang berorientasi pada rumusan tujuan yang baru. ${ }^{15}$ Upaya perubahan pendidikan pesantren tidak akan memiliki ujung akhir, karena persoalan pendidikan akan selalu ada selama peradaban dan kehidupan manusia itu sendiri masih ada, terlebih dalam era informasi seperti dewasa ini.

Perubahan pendidikan pesantren terjadi karena adanya tantangan kebutuhan masyarakat pada saat itu dan pendidikan pesantren itu sendiri diharapkan dapat menyiapkan produk manusia yang mampu mengatasi kebutuhan masyarakat tersebut. Berdasarkan pemikiran-pemikiran tersebut, karenanya perubahan pendidikan pesantren kini menjadi usaha yang harus segera dilakukan, jika pendidikan pesantren di Indonesia tidak menginginkan ketertinggalan dengan perkembangan zaman dan tersisih dari pentas global.

\section{Pola Lama Pendidikan Pesantren}

Pesantren merupakan asrama dan tempat para santri belajar ilmu agama juga ilmu yang bersifat umum dan di didik untuk bagaimana hidup mandiri. ${ }^{16} \mathrm{Hal}$ ini adalah merupakan faktor yang sangat penting utamanya dalam menanggulangi kemerosotan akhlak muda mudi, yang mana disebabkan dengan perkembangan ilmu pengetahuan dan teknologi sekarang ini, bukan hanya berpusat di kota-kota besar akan tetapi justru dapat merangkul sebagian besar pelosok pedesaan.

M. Dawam Raharjo, menjelaskan dalam bukunya "Pesantren dan Pembaharuan", pesantren merupakan lembaga Tafaqquh fi al-Din mempunyai fungsi pemeliharaan, pengembangan, penyiaran dan pelestarian Islam, dari segi kemasyarakatan, ia menjalankan pemeliharaan dan pendidikan mental.17 Bertolak dari uraian tersebut di atas, maka dapatlah diketahui bahwa dengan berdirinya pondok pesantren dari kota sampai ke pelosok-pelosok desa, telah dirasakan oleh masyarakat seperti adanya bakti sosial bersama dengan masyarakat maupun dalam bidang keagamaan yaitu dengan adanya pengajianpengajian atau ceramah-ceramah yang dilaksanakan baik terhadap masyarakat umum maupun terhadap santri itu sendiri.

Sebagai lembaga pendidikan Islam tradisional, pesantren memiliki kecenderungan untuk mempertahankan tradisi yang berorientasi pada pikiranpikiran ulama ahli fiqh, hadits, tafsir dan tasawuf yang hidup antara abad 7 sampai dengan abad 13, sehingga muncul kesan yang melekat bahwa dalam

\footnotetext{
15 Jusuf Amir Faisal, Reorientasi Pendidikan Islam (Jakarta: Gema Insani Press, 1995), 65.

16 Mas'ud Khasan Abdul Qahar, et. Al., Kamus Pengetahuan Populer (Yogyakarta: Bintang Pelajar, t.th), 191.

17 M. Dawam Raharjo, Pesantren dan Pembaharuan (Jakarta: LPES, 1974), 83.
} 
beberapa hal muslim tradisional mengalami stagnasi. ${ }^{18}$ Hal ini tampak pada beberapa hal yang menjadi ciri umum pesantren yang mempertahankan pola lama, antara lain:

1. Fisik

Hasil penelitian Arifin di Bogor menunjukkan adanya lima macam pola fisik pondok pesantren, yang apabila diklasifikasikan pada pola lama dan modern, nampak bahwa pola pertama, kedua dan ketiga, merupakan pola lama 19

Sementara menurut Zimek dalam mengklasifikasikan unsur-unsur kelengkapan pesantren, membagi menjadi lima tipe. ${ }^{20}$ Dari lima tipe tersebut sudah dicermati menunjukkan kategori jenis lama dan modern. Untuk jenis lama antara lain: pertama, jenis A. yaitu merupakan jenis pesantren yang paling sederhana. Biasanya dianut oleh para Kiai yang memulai pendirian pesantren. Dan elemennya pun disamping Kiai hanya ada masjid dan santri. Dengan demikian aktivitasnya pun maksimal hanya pada kitab-kitab Islam dan penguasaan serta pemahamannya. Usaha dititik beratkan sekedar pada usaha menarik santri. Kedua, jenis B. Yaitu pesantren yang lebih tinggi tingkatannya, terdiri dari komponen-komponen; Kiai, masjid, pondok, dan santri. Dimana pondok berfungsi sebagai tempat untuk menampung para santri agar lebih dapat berkonsentrasi dalam mempelajari agama Islam.

Menurut Nurcholis Madjid, dalam menyoroti aspek lingkungan, bahwa lingkungan pesantren merupakan hasil pertumbuhan tidak berencana, pengaturan tata kota, meskipun merupakan ciri khas namun terkesan kurang direncanakan secara matang, sehingga perkembangannya cenderung sporadis. ${ }^{21}$ Kamar asramanya sempit, pendek, cendela terlalu kecil dan pengaturannya pun semrawut, selain itu minim peralatan. Jumlah kamar mandi dan WC tidak sebanding dengan penghuni pondok, bahkan ada yang tidak menyediakan fasilitas ini, sehingga para santrinya mandi dan buang air di sungai. Kalaupun ada kondisinya tidak memenuhi syarat sistem sanitasi modern dan sehat. Halamannya tidak teratur, gersang, dimusim kemarau gersang, dimusim hujan becek, kadang-kadang sampah berserakan di sana sisni.

Madrasah atau ruangan kelas yang digunakan belajar kurang memenuhi persyaratan metodik-didaktik atau ilmu pendidikan yang semestinya, seperti

18 Zamakhsyari Dhofier, Tradisi Pesantren: Tradisi Pesantren : Studi tentang Pandangan Hidup Kiai (Jakarta : LP3ES, 1994), 1.

19 Imran Arifin, Kepemimpinan Kiai: Kasus Pondok Pesantren Tebu Ireng (Malang :

Kalimasahada Press, 1993),7.

20 Ziemek, Pesantren Dalam Perubahan Sosial, (Jakarta: P3M, 1986), 37.

${ }^{21}$ Nurcholis Madjid, Bilik-Bilik Pesantren (Jakarta: Paramadina, 1997), 92.

Jurnal Pendidikan Agama Islam

Volume 4 Nomor 2 Nopember 2016

ISSN(p) 2089-1946\& ISSN(e) 2527-4511

Hal. 256 - 270 
ukuran yang terlalu sempit atau terlalu luas. Antara dua ruang kelas tidak dipisahkan oleh suatu penyekat, ataupun kalau ada penyekatnya tidak tahan suara sehingga gaduh. Perabotnya yang berupa bangku, papan tulis, dan lainlain juga kurang mencukupi baik dari segi kualitas maupun kuantitasnya. Tempat ibadah biasanya mengecewakan, laantainya kotor, tempat wudlu-nya ditempat yang keruh dan kotor, arsitek bangunannya tidak menunjukkan efesiensi dan kerapian, penerangan terbatas, dan lain-lain.

2. Non Fisik

Dikaji dari aspek non fisik, pesantren pola lama sistem pengajarannya berbentuk non klasikal, dengan metode pengajaran berbentuk; sorogan, wetonan, bandongan, halaqah dan hapalan, ${ }^{22}$ dengan mengkaji kitab awal; cabang ilmu fiqh meliputi: Safinatul al-Sholah, Safinatu al-Najah, Fathu alQarib, Taqrib, Fathu al-mu'in, Minhaju al-Qawiem, Mutmainnah al-Iqnah, Fathu al-Wahab. Cabang ilmu tauhid meliputi; Aqidatu al-awwam (Nadzham), bad'u al-amal (Nadzham), dan sanusiyah. Cabang ilmu tasawuf; al-Nasha'ih-u alDiniyah, irsyadu al-'Ibad, Tanbighu al-Ghafilin, Minhaj al-'Abidin, al-Da'wat-u al-Tammah, al-Hikam, Risalat-u al-Mu'awanah wa al-Muzhaharah, Bidayat-u Al-Hidayah. Cabang Ilmu Nahwu Sharaf; al-Maqsud (nazham), 'Awamil (nazham), Imrithi (nazham), Ajurumiyah, Kaylani, Mirwat-u al-I'rab, Alfiyah (nazham), Ibnu al-'Aqil, dan dalam bidang akhlaq adalah ta'lim al-Muta'allim.

Sistem, materi dan metode kajian diatas, dipandang dari sudut pengembangan intelektual, sistem ini hanya bermanfaat bagi santri yang cerdas, rajin dan mampu, serta bersedia mengorbankan waktu yang cukup besar untuk studi ini. ${ }^{23}$ Dari segi pola kepemimpinan, cendrung Kiai sentris dengan manajemen otoritarinistik, yang pada akhirnya kurang perspektif, apabila meninggal dunia, maka pesantren gulung tikar. ${ }^{24}$ Dalam mempertahankan karisma, Kiai memelihara prinsip keep distance atau keep aloof, yakni jaga jarak ketinggian dengan para santri. Cenderung religiofeodalisme, yakni menjadi pemimpin agama sekaligus merupakan traditional mobility dalam masyarakat feodal, dan feodalisme yang terbungkus keagamaan ini bila disalahgunakan jauh lebi berbahaya dari pada feodalisme biasa. Dan tidak memiliki kecakapan teknis, sehingga menjadi salah satu sebab pokok tertinggalnya pesantren dari perkembangan zaman.

yang tidak terjembatani antara Kiai serta keluarganya disatu pihak dan para Menurut Abdurrahman Wachid walaupun telah dibentuk pengurus yang bertugas melaksanakan segala sesuatu yang berhubungan dengan jalannya

22 Mastuhu, Dinamika Sistem Pendidikan Pesantren (Jakarta, INIS, 1994), 61.

23 Karel A. Steenbrink, Pesantren Madrasah Sekolah (Jakarta: LP3ES, 1989), 17.

${ }^{24}$ Fadjar, A.Malik, Madrasah dan Tantangan Modernitas (Bandung: Mizan, 1998), 114. 
pesantren sehari-hari, kekuasaan mutlak senantiasa masih berada di tangan sang Kiai. Karenanya, betapa demokratisnya susunan pimpinan di pesantren, masih terdapat jarak asatid dan santri di pihak lain; Kiai cenderung bertindak sebagai pemilik tunggal Directeur eingenaur. Kedudukan yang dipegang seorang Kiai adalah kedudukan ganda sebagai pengasuh dan sekaligus pemilik pesantren dan secara kultura kedudukan ini sama dengan kedudukan bangsawan yang biasa dikenal dengan nama kanjeng di pulau Jawa. ${ }^{25}$

Dari aspek prilaku santri; menggeluti kehidupan sufistik, melalui wirid dan ngalab berkah pada kuburan Kiai tua dalam berpakaian, songkok danb sarung kurang dapat membedakan anatara pakaian belajar dengan pakaian tidur. ${ }^{26}$ Dalam bertingkah laku cenderung liberal dalam pesantren, tetapi rendak dan minder dalam tata pergaulan dengan masyarakat luas. Dan perilaku yang paling tidak simpatik adalah praktek para penghuni pondok (kamar) yang bertentangan dengan ajaran moral Islam.

\section{Dinamika Kelembagaan Pesantren; Sketsa Historis}

Sejak awal, pendidikan Islam telah mendapat prioritas utama bagi masyarakat Muslim, didorong kepentingan islamisasi yang telah mengarahkan umat Islam untuk melaksanakan pengajaran Islam sekalipun dalam sistem sederhana seperti halaqah yang dilakukan di tempat-tempat ibadah; masjid, mushalla bahkan di rumah ulama. ${ }^{27}$ Islamisasi tersebut, juga mendorong untuk mengadopsi dan mentransfer lembaga keagamaan dan sosial yang sudah ada saat itu ke dalam lembaga pendidikan Islam di Indonesia. Di Jawa umat Islam mentransfer lembaga keagamaan Hindhu Budha menjadi Pesantren, ${ }^{28}$ di Minangkabau misalnya, mengambil alih surau sebagai peninggalan adat masyarakat setempat menjadi lembaga pendidikan Islam, dan di Aceh mentransfer meunasah dan dayah sebagai lembaga pendidikan Islam. Sebagaimana pernyataan Haidar Putra Daulay, pendidikan Islam pada mulanya berlangsung secara tradisional, dilaksanakan di Surau, Masjid, Meunasah, Rangkang, Dayah, ataupun Pesantren. Pendidikan di tempat tersebut dipimpin langsung oleh ulama. ${ }^{29}$ Yang berkembang dan banyak memberi corak

\footnotetext{
${ }^{25}$ Abdurrahman Wahid, Bunga Rampai Pesantren (Jakarta: Darma Bhakti, 1994), 46.

${ }^{26}$ Madjid, Bilik-bilik Pesantren, 93.

27 Ulama, di Jawa disebut dengan panggilan Kiai, di Minagkabau disebut dengan Abuya atau Inyik, di Aceh disebut dengan Tengku. Lihat Haidar Putra Daulay, Historisitas, dan Eksistensi Pesantren, Sekolah dan Madrasah (Yogyakarta: PT. Tiara Wacana, 2001), 1.

${ }^{28}$ Lihat Hasan Muarif Ambary, Menemukan Perdaban; Jejak Arkeologis dan Historis Islam di Indonesia ( Jakarta: Logos Wacana Ilmu, 1998) 55-56.

${ }^{29}$ Daulay, Historisitas, dan Eksistensi Pesantren, Sekolah dan Madrasah, 1.
} 
pendidikan Islam di Indonesia kemudian, adalah Pesantren. ${ }^{30}$ Menurut Zamakhsyari Dhofier, istilah pesantren berasal dari kata santri, dengan awalan pe-dan akhiran -an, berarti tempat tinggal santri. ${ }^{31}$

Pesantren telah ada pada abad ke-15 yang didirikan di antaranya oleh Walisongo di samping ulama lainnya, meskipun banyak yang menilai tidak ada bukti-bukti kapan pesantren pertama muncul atau dirikan. Namun, akar dan embrio pesantren seperti ditulis Abdurrahman Mas'ud, bisa dilacak sejak periode Walisongo. ${ }^{32}$ Pada mulanya sistem (dalam pengertian sederhana) pendidikan masa Walisongo -yang dapat disebut unsur-unsur pesantren saat itu, adalah Masjid, Asrama dan Santri serta Kiai.

Di Minangkabau lembaga pendidikan Islam seperti Pesantren disebut Surau, dan di Aceh disebut Dayah atau Madrasah, dan Meunasah. ${ }^{33}$ Tempattempat itu pada mulanya ada yang berfungsi sebagai tempat berkumpul atau rapat (surau), sebagai tempat ibadah di setiap kampung (meunasah), dan sebagai tempat belajar dan shalat berjama'ah (dayah). Dayah dan meunasah ini dibedakan hanya oleh materi belajar yang disajikan di dayah lebih tinggi. Kesemuanya mengalami proses Islami.

Lembaga-lembaga pendidikan tersebut merupakan lembaga-lembaga pendidikan yang vital di Indonesia. Lembaga seperti inilah yang sangat berarti untuk mengajarkan nilai-nilai Islam. Melalui lembaga tersebut Islam mengakar kuat di Nusantara, sampai akhirnya datang kolonialisme yang membawa jargon westernisasi, modernisasi, sekaligus kolonialisasi. Di mana tidak lama implikasi yang nyata dari "makhluk" berbahaya ini adalah terhapusnya beberapa lembaga pendidikan Islam. Dan tinggal yang eksis adalah pesantren. Pesantren kuat dan eksis tidak lebih didukung oleh fungsi pesantren saat itu. Yaitu di masa sebelum datang kolonialisme pesantren selain sebagai tempat pendidikan keagamaan, juga menjadi semacam "balai pendeta", tempat para Sultan berkonsultas kepada para Wali mengenai urusan pribadi maupun kenegaraan,

\footnotetext{
${ }^{30}$ Fatah Syukur NC bahkan memasukkan sub dari sub judul Bab II dengan tema Pesantren sebagai akar pendidikan Islam di Indonesia. Ia menegaskan pesantren merupakan lembaga pendidikan Islam tertua di Indonesia, dan merupakan akar berdirinya madrasah yang mewarisi beberapa nilai budaya yang telah berkembang di pesantren. Fatah Syukur NC, Dinamika Madrasah dalam Masyarakat Industri (Semarang : al-Qalam Press Semarang , 2004), .26 dan 32.

31 Zamakhsyari Dhofier, Tradisi Pesantren (Jakarta: LP3ES, 1994), Cet. 6, 18.

32 Abdurrahman Mas'ud, Intelektual Pesantren,; Perhelatan Agama dan Tradisi (Yogyakarta: LKiS, 2004), 77.

33 Keterangan lebih banyak dan lengkap tentang lembaga-lembaga tersebutdapat dilihat dalam Imam Bawani, Tradisionalisme dalam Pendidikan Islam (Surabaya: Al-Ikhlas, 1993), 88.
} 
sehingga pesantren memiliki posisi kuat. Sedangkan pada masa penjajahan kolonial kondisi pesantren menjadi oposisi utama di mana ia menjadi pilar pergerakan perlawanan umat Islam terhadap penjajah.

Selanjutnya, sejak Belanda mendirikan lembaga pendidikan umum, sekolah rakyat atau sekolah Desa dengan masa belajar selama 3 tahun di beberapa tempat di Indonesia pada tahun 1870-an telah mempengaruhi lembaga pendidikan Islam, Perkembangan selanjutnya tradisi baru pendidikan itu menjadi inkulturalisasi terhadap tradisi Asli pesantren atau surau. Banyak pesantren atau surau melakukan perubahan. Misalnya memasukkan mata pelajaran umum. Tidak hanya itu saja, ada pesantren atau surau berubah menjadi madrasah dan berubah dari fungsi aslinya.

Dalam masa-masa kesulitan ekonomi yang terjadi di Indonesia pada dekade 1950-an dan awal 1960-an, pembaharuan pesantren banyak berkenaan dengan pemberian ketrampilan khususnya dalam bidang pertanian. Santri diharapkan mempunyai bekal dan untuk mendukung ekonomi pesantren. Karena pada saat itu terjadi krisis ekonomi sehingga banyak pesantren di pedesaan seperti Tebuireng dan Rejoso, mengarahkan pada santrinya untuk terlibat dalam kegiatan-kegiatan vacational dalam bidang pertanian seperti penanaman padi, kelapa, tembakau, kopi dan lainnya. Hasil penjualan dari usaha pertanian seperti itu digunakan untuk membiayai pesantren.

Pada waktu itu, pesantren-pesantren besar seperti Gontor, Tebuireng, Denanyar, Tambak beras, Tegalrejo mulai mendirikan dan mengembangkan koperasi. Dengan koperasi ini, minat kewirausahaan para santri dibangkitkan. Untuk kemudian diarahkan menuju pengembangan pengelolaan usaha-usaha ekonomi pesantren dan pengembangan ekonomi masyarakat.

Setelah pesantren dan sistem kelembagaan madrasah modern berada di bawah tanggung jawab dan pengawasan Departemen Agama maka banyak pesantren yang mendirikan madrasah. Pesantren mengalami perubahan yang sangat signifikan karena berlangsungnya modernisasi pesantren di Jawa sejak masa orde baru. Dalam perubahan-perubahan itu, pesantren kini memiliki empat jenis pendidikan. "Pertama, pendidikan yang berkonsentrasi pada tafaqquh fi aldin, kedua, pendidikan berbasis madrasah, ketiga, pendidikan berbasis sekolah umum dan keempat, pendidikan berbasis ketrampilan". ${ }^{34}$

Hal ini berbeda dengan apa yang dimaksudkan oleh Dr.Budiono, Ka.Balitbang DepDiknas RI, pada dasarnya pemerintah melalui sistem pendidikan nasionalnya mencoba memayungi lebih nyata seluruh jalur pendidikan di negeri ini tanpa ada diskriminasi pendidikan. Menurutnya

34 Azyumardi Azra, Surau, Pendidikan Islam Tradisional dalam Transisi dan Modernisasi (Jakarta : Logos Wacana Ilmu, 2003), 148.

Jurnal Pendidikan Agama Islam

Volume 4 Nomor 2 Nopember 2016

ISSN(p) 2089-1946\& ISSN(e) 2527-4511

Hal. 260 - 270 
sekarang ini madrasah dan pesantren selalu termarginalkan oleh pemerintah, padahal pesantren merupakan lembaga pendidikan tertua di Indonesia yang sudah banyak memberikan pengaruhnya di tengah-tengah kehidupan masyarakat. Dengan demikian Budiono mengharapkan perubahan-perubahan yang terjadi di pesantren dapat memberikan konstribusi pemikiran dalam menentukan arah serta warna pendidikan nasional di masa depan. Budiono juga sadar, pesantren dan sekolah lainnya memiliki kelebihan dan kekurangan masing-masing, akan tetapi melalui kerjasama bersifat kemitraan antara pemerintah dan masyarakat, kekurangan tersebut dapat diminimalisir. 35

Sebenarnya persoalan yang kemudian timbul dari perubahan madrasah yaitu menyangkut pembedaan antara lembaga umum dan lembaga agama, ketika madrasah dijadikan sekolah umum atau sama dengan sekolah umum maka sulit bagi kita menyebutkan mana yang berorientasi pada ilmu agama atau mengajarkan ilmu agama ? karena madrasah sekarang diharuskan mengikuti program-program pengajaran yang sama dengan sekolah umum dari pemerintah. Hal ini madrasah menjadi tidak independent.

Modernisasi pesantren telah banyak mengubah sistem dan kelembagaan pendidikan pesantren. Perubahan yang sangat mendasar misalnya terjadi pada aspek-aspek tertentu dalam kelembagaan. Modernisasi pesantren selama ini telah merubah fungsi utamanya sebagai reproduksi ulama. Fungsi pesantren menjadi luas karena adanya berbagai tuntutan dan kebutuhan zaman. Fungsi ganda pesantren yaitu bidang keagamaan dan umum akan menghilangkan identitas pesantren sebagai pendidikan tradisional. Dalam pandangan lain Nurcholish Madjid mengatakan : "Dunia pendidikan Islam harus memodernisasi diri guna mengejar ketinggalannya dan untuk memenuhi tuntutan teknologi di masa depan."36

Perkembangan terakhir menunjukkan ada pesantren khusus yang menitik beratkan pada teknologi tertentu, seperti peternakan, pertanian, perikanan, dan lainnya. Pesantren melakukan perubahan tersebut sebagai respon terhadap pendidikan umum yang terlebih dahulu mengembangkan MIPA.

Sistem pendidikan Islam tradisional khususnya pesantren yang melakukan usaha modernisasi, usaha-usaha melakukan pembaharuan misalnya muncul pesantren pertanian, peternakan, pesantren perikanan dan sebagainya. Eksperimen pesantren tersebut mencoba meniru Al-Azhar. Gagasan ini masih

35 Budiono, Eksistensi Pesantren Di Tengah Perubahan Sistem Pendidikan Nasional, http://www.maarif-nu.or.id/dunia_pddk/opini/eksistensi_pesantren_di_tengah.htm.

Diakses pada 16 Desember 2016.

36 Yasmadi, Modernisasi Pesantren, Kritikan Nurcholish Madjid Terhadap Pendidikan Islam Tradisional (Jakarta : Ciputat Press, 2002), 133. 
belum konkrit tentang konsep secara epistemologi keilmuan umum dalam wacana pendidikan Islam sekarang.

Sejalan dengan fungsi dari kelembagaan pesantren, Arief Subhan menambahkan, selama ini pesantren telah menjalankan fungsinya tidak hanya sebagai lembaga pendidikan, yaitu mengajarkan ilmu-ilmu tradisional Islam, tetapi lebih dari itu, sebagai penjaga dan pemelihara tradisi-tradisi Islam dan sebagai sumber repoduksi otoritas keislaman di lingkungan masyarakat Muslim.

\section{E. Pergeseran Orientasi Kelembagaan Pesantren dalam Persepektif Kiai di Bangkalan Madura}

Secara terorganisir, modernisasi pendidikan Islam terjadi abad ke-20. Pada abad ini, dunia Islam termasuk Indonesia telah dimasuki semangat pembaruan dan pencerahan. Yaitu banyaknya orang dan organisasi Islam tidak puas dengan metode tradisional dalam mempelajari al-Qur'an dan studi keIslaman. Mengingat pendidikan merupakan kebutuhan penting bagi setiap manusia, negara dan bangsa, maka pendidikan harus selalu diperbarui, diberdayakan dan dikembangan secara sistematis, khususnya oleh beberapa pondok pesantren di negara ini termasuk pesantren di Bangkalan.

Berangkat dari kerangka demikian ini, maka upaya pendidikan suatu bangsa berkaitan erat dengan rekayasa bangsa tersebut di masa mendatang, sebab pendidikan selalu dihadapkan pada perubahan, baik perubahan zaman maupun masyarakat. Oleh karena itu, pesantren di Bangkalan mau tidak mau pendidikannya harus didesain mengikuti irama perubahan tersebut, kalau tidak maka pendidikannya akan ketinggalan. Tuntutan pembaruan pendidikan di pesantren juga menjadi suatu keharusan dan pembaruan pendidikan selalu mengikuti dan relevan dengan kebutuhan masyarakat, baik pada konsep, kurikulum, proses, fungsi, tujuan, manajemen lembaga-lembaga pendidikan, dan sumber daya pengelola pendidikan.

Setelah pesantren dan sistem kelembagaan madrasah modern berada di bawah tanggung jawab dan pengawasan Departemen Agama, maka banyak pesantren yang mendirikan madrasah. Pesantren mengalami perubahan yang sangat signifikan karena berlangsungnya modernisasi pesantren di Jawa sejak masa orde baru. Ada anggapan bahwa perubahan kelembagaan dari non formal ke formal yang terjadi di pesantren dapat memberikan konstribusi pemikiran dalam menentukan arah serta warna pendidikan nasional di masa depan. Oleh karena itu banyak pondok pesantren yang mengalami perubahan kelembagaannya demi majunya pendidikan nasional di masa yang akan datang. Perubahan kelembagaan di pesantren selama ini telah merubah fungsi utamanya 
sebagai reproduksi ulama. Fungsi pesantren menjadi luas karena adanya berbagai tuntutan dan kebutuhan zaman. Banyak Kiai mempunyai pemikiran bahwa pendidikan Islam di pesantren harus memodernisasi diri guna mengejar ketertinggalannya dan untuk memenuhi tuntutan teknologi di masa depan. Karena pesantren mempunyai potensi untuk berkembang.

Hal di atas searah dengan apa yang diungkapkan Hanun Asrohah tentang pesantren. Menurutnya, pesantren memiliki mekanisme internal untuk beradaptasi menjadi tren baru, karena perkembangan fungsi dan diferensiasi. Pengalaman empiris menunjukkan kemampuan empat fungsi penting dari pesantren, yaitu: kemampuan tinggi untuk beradaptasi ke dunia luar, prestasi luas tujuan, kemampuan integratif menyatukan aspek unik dari pesantren sebagai sub-budaya, dan kemampuan dalam melestarikan pesantren tradisi dengan adagium: "mempertahankan tradisi lama yang baik dan mendapatkan tradisi baik yang baru". ${ }^{37}$

Kiai merupakan bagian dari masyarakat Bangkalan yang sangat tidak terbantahkan. Kiai mempunyai pengaruh yang besar pada setiap sendi kehidupan masyarakat Bangkalan dalam segala aspek, seperti pendidikan, kuasa politik, ekonomi, sosial dan agama. sehingga sangat tidak mungkin mengilangkan tokoh Kiai dalam struktur masyarakat Bangkalan ini. Kiai dikenal oleh sebagian masyarakat Bangkalan dalam konstruk yang positif, yaitu orang yang pintar atau alim dalam pengetahuan agama Islam. Biasanya Kiai adalah pengasuh sebuah lembaga pendidikan Islam, baik lembaga pendidikan Diniah saja atau Pondok pesantren.

Kiai yang merupakan kepala pendidikan Islam yang awalnya tidak terlalu menerima pendidikan formal sekarang mengalami pergeseran pemikiran dan prilaku yang sangat berefek pada pendidikan di Bangkalan. Keterbukaan para Kiai di Bangkalan pada pendidikan formal dengan semakin banyaknya pesantren yang mempunyai kategori salafiyah mempunyai pendidikan formal mulai dari tingkat dasar hingga perguruan tinggi merupakan fenomena tersendiri bagi masyarakat Bangkalan.

Pergeseran orientasi kelembagaan dalam persepektif Kiai yang terjadi di Bangkalan pada kalangan struktur sosial tentu sangat berpengaruh pada perubahan pendidikan pesantren yang ada di Bangkalan, dalam hal ini penulis menjadikan Pondok Pesantren Syaichona Kholil Demangan Bangkalan dan Pondok Pesantren AL Hidayah Jangkebuwan Bangkalan.

37 Lihat Hanun Asrohah, "The Dynamics of Pesantren: Responses Toward Modernity and Mechanism in Organizing Transformation". JIIS: Jounal of Indonesian Islam Vol.5, No. 1 (2011). 
Pergeseran pemikiran pada golongan Kiai tersebut di atas mempunyai tujuan yang mungkin saja berbeda dari maksud sebuah proses pendidikan sebagaimana mesti dan lazimnya. Hal inilah yang akan penulis paparkan dan analisis bagaimana pergeseran orientasi kelembagaan dalam perspektif Kiai. Kiai tentu mempunyai pandangan tersendiri tentang kehadiran sekolah formalnya dimasing-masing lembaga pendidikan Islam yang ada di pesantren-pesantren.

1. Pergeseran Orientasi Kelembagaan Pesantren dalam Perspektif Kiai Di Pesantren Syaichona Cholil Bangkalan

Pesantren yang saat ini banyak melakukan perubahan pada sistem pendidikannya seperti merubah kelembagaannya dari sistem pendidikan salafiyah yang merupakan pendidikan non formal menjadi pendidikan formal seperti pendidikan Mts, MA, bahkan tak jarang pula sebuah pondok pesantren berlomba-lomba untuk mendirikan perguruan tinggi di pesantrennya. Hal ini juga terjadi pada pesantren Syaichona Cholil Bangkalan yang telah mengalami pembaruan pendidikan islam. Hal tersebut terjadi tentunya tidak lepas dari perubahan pola pikir dan perilaku Kiai yang telah banyak mengalami pergeseran orientasi kelembagaan dari sistem pendidikan non formal ke sistem pendidikan formal.

Perubahan pola pikir Kiai dari berubahnya pendidikan non formal ke formal yakni karena disebabkan perkembangan zaman yang semakin maju, teknologi yang semakin canggih, dan sulitnya bagi santri yang ingin mendapatkan peluang untuk mendapatkan pekerjaan di instansi umum atau pemerintah. KH. M. Nasih Aschal selaku ketua pengurus harian pondok pesantren Syaichona Kholil Bangkalan menyatakan:38

"Kalau kita tetap memberlakukan sistem pendidikan non formal saja tanpa merubahnya ke pendidikan formal, maka kita akan ketinggalan oleh perkembangan zaman, semakin kedepan arus ilmu pengetahuan dan teknologi akan semakin berkembang. Maka dari itu kita harus mengikutinya, lagi pula perubahan lembaga pendidikan dari non formal ke formal ini sangat penting karena saat ini pendidikan formallah yang diakui oleh Negara dan bisa melanjutkan keperguruan tinggi negri apabila si santri ingin melanjutkan diluar. Selain itu kita bisa memberikan peluang kepada santri untuk memilih apakah ingin sekolah di pendidikan yang formal, atau yang non formal.."

Dari pernyataan tersebut, dapat kita pahami bahwa dalam pergeseran orientasi kelembagaan pendidikan dari non formal ke formal dalam perspektif

38 Hasil wawancara dengan KH. M. Nasih Aschal selaku ketua pengurus harian pondok pesantren Syaichona Kholil Bangkalan, pada 15 November 2016. 
Kiai itu sangat penting dan menjadi sebuah keharusan mengingat pendidikan harus juga berkembang mengikuti perkembangan zaman.

Pola pikir Kiai sudah modern mengingat Bangkalan adalah suatu daerah yang dikenal agak primitif dari pada wilayah yang lain di jawatimur. Ini terlihat dari budaya cara masyarakatnya berpakaian, tempat tinggal, akses jalan yang tak terawatt dan lain sebagainya. Bangkalan juga terkenal dengan kota santri di mana hampir setiap penduduk memondokkan anaknya ke pesantren baik pesantren itu berada di daerah Bangkalan sendiri atau diluar Bangkalan.

Oleh karena itu Kiai sebagai panutan bagi masyarakat khususnya di daerah Bangkalan, mempunyai peranan penting dalam menentukan arah pendidikan pada masa yang akan datang di Bangkalan terutama di pondokpondok pesantren yang ada Bangkalan. Faktor sulitnya para alumni pesantren untuk bersaing dengan lulusan pendidikan yang lain telah merubah pola pikir Kiai yang dulunya masih konservatif menjadi modern dalam hal pendidikan sehingga para Kiai membenahi permasalahan-permasalahan umum yang terdapat di dalam pesantren yang telah menghambat para alumni pesantren untuk bersaing dengan lulusan lembaga pendidikan yang lain.

Adapun permasalahan-permasalahan umum itu yakni : (1) Aspek Kelembagaan Masih banyak pondok pesantren yang masih belum berbadan hukum, atau pengelolaannya masih secara individu, sehingga masih terdapat kesulitan dalam melakukan kerjasama dengan pihak luar. (2) Aspek kurikulum pendidikan di pondok pesantren masih terfokus pada pendidikan agama dengan sedikit penekanan pada ilmu pengetahuan umum dan teknologi sehingga lulusannya belum mampu berkompetisi dengan lulusan lembaga pendidikan lainnya dalam dunia kerja. (3) Aspek Sarana Prasarana Umumnya pondok pesantren belum memiliki ruang kelas, perpustakaan, laboratorium dan ruang ketrampilan yang cukup memadai untuk sebuah institusi pendidikan yang mengharapkan lulusannya dapat berprestasi. (4) Aspek Manajemen Banyak pesantren yang masih dikelola secara informal yang didasarkan pada asumsi bahwa pesantren sebagai lembaga tradisional tidaklah memerlukan legalitas formal, disebabkan oleh kebesaran pengaruh seorang Kiai sebagai figur sentral yang dikagumi dan dipanuti. (5) Aspek Pendanaan Faktor dana atau kebutuhan finansial pesantren, sebagian besar masih dipenuhi oleh pimpinan maupun pengelola pondok, sehingga cukup menjadi faktor pembatas dalam pengembangannya kedepan.

Hal ini diperkuat oleh pernyataan dari KH. M. Nasih Aschal selaku ketua pengurus harian pondok pesantren Syaichona Kholil Bangkalan berikut ini:

“...Coba ya, Anda perhatikan di pondok-pondok pesantren Bangkalan ini.. banyak para alumni pesantren kalah bersaing dengan lembaga pendidikan lain ini dikarenakan ada beberapa 
permasalahan-permasalahan yakni aspek kelembagaan masih di atur seorang Kiai saja, aspek kurikulum pendidikan di pondok pesantren masih terfokus pada pendidikan agama dengan sedikit penekanan pada ilmu pengetahuan umum, lalu sarana prasarana yang kurang, aspek manajemen banyak pesantren yang masih dikelola secara informal yang tidak mementingkan legalitas, masalah pendanaan atau kebutuhan finansial pesantren yang masih kurang.." 39

Dari pernyataan di atas, ternyata banyak pondok pesantren di Bangkalan yang masih bermasalah dalam lembaga pendidikannya. Ini terlihat bagaimana KH. M. Nasih Aschal memaparkan bahwa masih banyak pesantren yang informal dalam pengertian, pesantren yang menerapkan sistem pendidikannya hanya di ajari oleh Kiai.

Ini diperkuat oleh data yang penulis telusuri dari internet bahwa banyak pondok pesantren masih belum memiliki lembaga pendidikan umum seperti SMP dan SMA atau Madrasah Tsanawiyah dan Aliyah yang dikelola sendiri oleh pondok pesantren tersebut. Pihak Departemen Agama Kabupaten Bangkalan menyebutkan bahwa dari 329 pondok pesantren yang ada di kabupaten Bangkalan, hanya 115 pondok pesantren atau sebanyak 35\% dari dari total seluruh pondok pesantren di kabupaten Bangkalan yang memiliki Sekolah/Madrasah dengan kurikulum umum. ${ }^{40}$

Banyaknya pondok pesantren di Bangkalan yang mencapai 329 pondok pesantren disebabkan karena kultur budaya Madura khususnya Bangkalan, yang mempunyai keinginan untuk mendirikan pondok pesantren walaupun dari aspek sarana dan prasarana kurang memadai. Sehingga banyak pondokpondok pesantren kecil yang bertebaran di Bangkalan.

2. Pergeseran Orientasi Kelembagaan Dalam Perspektif Kiai Di Pesantren AlHidayah Bangkalan

Perubahan zaman yang telah terjadi pada saat ini sedikit banyak telah merubah segala aspek termasuk aspek pendidikan. Saat ini banyak pesantren di Bangkalan telah merubah lembaga pendidikannya dari non formal menjadi formal. Hal ini juga terjadi pada pondok pesantren Al-Hidayah Bangkalan. berubahnya kelembagaan pendidikan dari non formal ke formal tersebut juga tidak lepas dari perubahan pola pikir dari Kiai yang menilai bahwa dengan perubahan tersebut, pesantren tidak akan ketinggalan zaman dan para santri dapat bersaing dengan siswa yang sekolah di lembaga pendidikan umum yang lain.

39 Hasil wawancara dengan KH. M. Nasih Aschal selaku ketua pengurus harian pondok pesantren Syaichona Kholil Bangkalan, pada 02 Desember 2016.

$40 \mathrm{http} / / /$ pusatbahasaalazhar.wordpress.com/persembahan-buat-guru/\%E2\%80\%9Clife-skill-untukmeningkatkan-mutu-pendidikan-pesantren-sebagai-bagian-dari-usaha-pengembangan-sumberdaya-manusia-di-kabupaten-Bangkalan\%E2\%80\%9D/. Diakses pada 01 Desember 2016.

Jurnal Pendidikan Agama Islam

Volume 4 Nomor 2 Nopember 2016

ISSN(p) 2089-1946\& ISSN(e) 2527-4511

Hal. 266 - 270 
Hal ini sesuai dengan pernyataan dari KH. Afif Mahfudz Hadi selaku pengasuh pondok pesantren Al-Hidayah Bangkalan beliau mengatakan:

"Pesantren yang didalamnya mengajarkan pendidikan islam juga harus berubah mengikuti perkembangan zaman. Perubahan yang saya maksud adalah perubahan yang menuju ke arah yang lebih baik, misalnya seorang santri belajar tentang ilmu agama terus, sedangkan kehidupan ini tidak hanya membutuhkan ilmu agama saja, tetapi ilmu pengetahuan umum dan teknologi juga penting untuk kehidupan kita dan itu juga harus dikuasai oleh santri..." 41

Dari pernyataan di atas, dapat kita simpulkan bahwa Kiai tidak menghendaki para santri hanya paham tentang ilmu agama saja tetapi ilmu pengetahuan umum juga harus dikuasai. Ini artinya pelajaran umum harus dimasukkan kedalam sistem kurikulum pendidikan pesantren. Hal ini memang penting dan sesuai dengan apa yang di katakana oleh Nurcholish Madjid didalam buku "Modernisasi Pesantren, Kritikan Nurcholish Madjid Terhadap Pendidikan Islam Tradisional" dia mengatakan : "Dunia pendidikan Islam harus memodernisasi diri guna mengejar ketinggalannya dan untuk memenuhi tuntutan teknologi di masa depan.

Pergeseran orientasi kelembagaan dari non formal ke formal yang diterapkan didalam pesantren ini juga sedikit banyak dipengaruhi oleh kebanyakan masyarakat yang lebih ingin memasukkan anaknya ke lembaga pendidikan umum dari pada di pesantren. Ini disebabkan karena di pesantren yang tradisional tidak memasukkan pendidikan umum kedalam sistem pendidikannya sehingga bisa mengancam eksistensi pesantren dalam proses belajar-mengajarnya karena bisa jadi santri semakin lama akan semakin sedikit.

KH. Afif Mahfudz Hadi, selaku pengasuh pondok pesantren Al-Hidayah Bangkalan, mengatakan bahwa:

“...Masyarakat sekarang sudah agak enggan memasukkan anaknya ke pesantren salaf, beda dengan zaman dulu. Zaman sekarang pesantren yang ada kurikulum negeri dan bisa menyelenggarakan atau mengikuti ujian negara maka pesantren tersebut akan mampu mempertahankan jumlah santrinya. Sebaliknya, pesantren yang tidak mau menerima kurikulum negeri yang berarti tidak bisa mengikuti ujian Negara lama-lama akan menjadi berkurang jumlah santrinya. Nah, oleh karena itu, untuk mempertahankan eksistensi pesantren Al-Hidayah ini maka sistem pendidikannya sangat perlu dimasukkan kurikulum negeri dan bisa mengikuti ujian negara, agar para santri bisa mempunyai ijazah yang sah dari Negara..."42

Dari penyataan KH. Afif Mahfudz Hadi di atas, jelas bahwa pada era sekarang ini pesantren harus ikut perkembangan zaman agar eksistensinya tetap terjaga dan jumlah santri tidak berkurang dengan cara memasukkan kurikulum negeri kedalam sistem pendidikan di pondok pesantren.

${ }^{41}$ Hasil wawancara dengan KH. Afif Mahfudz Hadi pengasuh pondok pesantren Al-Hidayah Bangkalan, pada 07 Desember 2016.

42 Hasil wawancara dengan KH. Afif Mahfudz Hadi pengasuh pondok pesantren Al-Hidayah Bangkalan, pada 29 November 2016. 
Penulis menilai pandangan Kiai tentang akan berkurangnya santri yang mondok di pondok pesantren tradisional (tidak diterapkannya kurikulum negeri atau lembaga pendidikan formal) sangat menarik dan rasional, karena perkembangan zaman yang semakin modern tanpa kita sadari telah merubah pola pikir masyarakat. Oleh karena itu pesantren sebagai lembaga pendidikan islam, perlu melakukan pembaruan pendidikan islam agar eksistensi pesantren tetap terus terjaga.

\section{F. Kesimpulan}

Pada bagian ini, penulis memaparkan kesimpulan dari penelitian ini yakni pergeseran orientasi kelembagaan dalam persepektif Kiai yang terjadi di pondok pesantren Syaichona Kholil dan Al-Hidayah Bangkalan yaitu para Kiai telah mengalami perubahan paradigma dan perilaku dengan keterbukaannya dan menerima pendidikan formal masuk ke dalam sistem pendidikan di pesantren yang awalnya berkarakter tradisional. Perubahan sikap Kiai ini semata-mata bertujuan agar eksistensi pesantren selalu tetap terjaga dalam memasuki era modernisasi. Dengan pergeseran orientasi kelembagaan tersebut, maka terjadi perubahan yang signifikan pada 2 pondok pesantren di Bangkalan ini. Di pondok pesantren Syaichona Kholil Bangkalan misalnya. Pengasuh memasukkan pelajaran-pelajaran umum ke dalam sistem pendidikan di pesantren dengan mendirikan lembaga formal seperti MTs, SMA, hingga Perguruan Tinggi Islam Syaichona Kholil; Sekolah Tinggi Agama Islam Syaichona Kholil (STAIS). Selain itu, pesantren Syaichona Kholil juga telah menyesuaikan diri dengan perkembangan zaman dengan mengembangkan beberapa komponen seperti pengembangan struktur, pengembangan sistem pendidikan, dan pengembangan sarana dan prasarana. Sedangkan perubahan yang terjadi di pondok pesantren Al-Hidayah Bangkalan hampir sama dengan pondok pesantren Syaichona Kholil dengan memasukan pelajaran-pelajaran umum ke dalam sistem pendidikan dipesantren dengan mendirikan lembaga formal seperti MI, MTs, dan MA. Namun perbedaanya, pondok pesantren Al-Hidayah tidak sampai mendirikan perguruan tinggi sebagaimana pondok pesantren Syaichona Kholil. Selain itu pesantren AlHidayah juga melakukan pembaruan pendidikan dengan mewajibkan kepada santrinya untuk selalu berbahasa asing baik bahasa arab maupun bahasa inggris dalam kegiatan sehari-harinya. Serta melatih para santri dengan pendidikan life skill seperti kerajinan tangan dengan membuat kaligrafi, sablon dan buat gantungan kunci. 


\section{G. Referensi}

Amir Faisal, Jusuf, Reorientasi Pendidikan Islam, Jakarta: Gema Insani Press,1995. Anwar, Muhammad. "Modernisasi Pesantren; Pergeseran Tradisi dan Pudarnya Kiai”. Hunafa: Jurnal Studia Islamika Vol. 10, No. 1, (Juni 2013).

Arifin, Imran. Kepemimpinan Kiai: Kasus Pondok Pesantren Tebu Ireng. Malang: Kalimasada Press, 1993.

Asrohah, Hanun. Sejarah Pendidikan Islam. Jakarta : Logos Wacana Ilmu, 1999. . "The Dynamics of Pesantren: Responses Toward Modernity and Mechanism in Organizing Transformation". JIIS: Jounal of Indonesian Islam Vol.5, No. 1 (2011).

Azra, Azumardi. "Pesantren : Kontinuitas dan Perubahan", Pengantar dalam

Nucholis Madjid, Bilik-Bilik Pesantren : Sebuah Potret Perjalanan Jakarta : Paramida, 1997.

.Pendidikan Islam; Tradisi dan Modernisasi Menuju Milenium Baru, Jakarta: Logos Wacana Ilmu, 1999.

Surau, Pendidikan Islam Tradisional Dalam Transisi Dan Modernisasi. Jakarta: Logos Wacana Ilmu, 2003.

Bruinessen, Martin Van. Kitab Kuning, Pesantren, dan Tarekat : Tradisi-Tradisi Islam di Indonesia. Bandung : Mizan, 1999.

Budiono, Eksistensi Pesantren Di Tengah Perubahan Sistem Pendidikan Nasional, http://www.maarifnu.or.id/dunia_pddk/opini/eksistensi_pesantren_di_tengah.htm.

NC, Fatah Syukur. Dinamika Madrasah dalam Masyarakat Industri. Semarang : alQalam Press Semarang , 2004.

Daulay, Haidar Putra. Historisitas, dan Eksistensi Pesantren, Sekolah dan Madrasah. Yogyakarta: Tiara Wacana, 2001.

Dhofier, Zamakhsyari. Tradisi Pesantren : Studi tentang Pandangan Hidup Kiai. Jakarta : LP3ES, 1994.

Eksan, Moch., Kiai Kelana: Biografi Kiai Muchith Muzadi. Jogjakarta: Elkis Penlangi Aksara, 2000.

Faisal, Jusuf Amir. Reorientasi Pendidikan Islam. Jakarta: Gema Insani Press, 1995.

Hasan, Muhammad. "Inovasi dan Modernisasi Pendidikan Pondok Pesantren". KARSA: Jurnal Sosial dan Budaya Keislaman Vol. 23 No. 2, (Desember 2015): 296-298. 
Kafrawi, H. Pembaharuan Sistem Pendidikan Pesantren. Jakarta: Cemara Indah, 1978.

Madjid, Nurcholish. Bilik-Bilik Pesantren : Sebuah Potret Perjalanan. Jakarta : Paramadina, 1997.

Madjid, Nurcholish. Islam, Kemodernan, dan Keindonesiaan. Bandung : Mizan, 1997.

Malik, A. Fadjar. Madrasah dan Tantangan Modernitas (Bandung: Mizan, 1998), 114.

Mas'ud, Abdurrahman, Intelektual Pesantren,; Perhelatan Agama dan Tradisi, Yogyakarta: LKiS, 2004

Mastuhu,. Dinamika Sistem Pendidikan Pesantren. Jakarta: INIS, 1994.

Qahar, Mas'ud Khasan Abdul. Kamus Pengetahuan Populer. Yogyakarta: Bintang Pelajar, t.th.

Raharjo, M. Dawam. Pesantren dan Pembaharuan. Jakarta: LPES, 1974.

Rahman, Fazlur, Islam dan Modernitas: Tantangan Transformasi Intelektual, Terj. Ahsin Muhammad, Bandung: Pustaka, 1995, Cet. II.

Siradj, Said Aqil. Pesantren Masa Depan, Wacana Pemberdayaan dan Transformasi Pesantren. Bandung : Pustaka Hidayah, 1999.

Steenbrink, Karel A, Pesantren, Madrasah, Sekolah Pendidikan Islam dalam Kurun Modern, Jakarta: LP3ES, 1986

Subaharianto, Andang, dkk, Tantangan Industrialisasi di Madura. Malang: Bayumedia Publishing, 2004.

Undang-Undang RI No. 20 Tahun 2003 tentang Sistem Pendidikan Nasional, Bandung: Citra Umbara: 2003.

Usa, Muslih. Pendidikan Islam di Indonesia Antara Cita dan Fakta, Yogyakarta: PT. Tiara Wacana, 1991.

Wahid, Abdurrahman. Bunga Rampai Pesantren. Jakarta: Darma Bhakti, tt.

Yasmadi. Modernisasi Pesantren : Kritikan Nurcholis Madjid Terhadap Pendidikan Islam Tradisional. Jakarta : Ciputat Press, 2002.

Ziemek, Pesantren Dalam Perubahan Sosial, Jakarta: P3M, 1986. 